\section{Bullying Survivors: The Dynamic of Frequency, Forms of Bully and The Response of Survivors}

Cicilia Tanti Utami ${ }^{1,5}$, M.G. Adiyanti ${ }^{2}$, Bhina

Patria $^{3}$ Wenty Marina Minza ${ }^{4.5}$

${ }^{1}$ Fakultas Psikologi

Universitas Katolik Soegijapranata-Semarang

2,3,4 Fakultas Psikologi

Universitas Gadjah Mada-Yogyakarta.

email : adiyanti_psy@ugm.ac.id
Journal PSIKODIMENSIA

Volume 19, No. 1,

Januari - Juni 2020

ISSN cetak : 1411-6073

ISSN online : 2579-6321

DOI:10.24167/psidim.v19i1.2450

\begin{abstract}
This research used a descriptive method to obtain description about the unpleasant experience of students in school. Subjects are 731 students from six high schools in Semarang city. Method of data collection using scale. The results showed that students who admitted to get unpleasant treatment in the frequent category were $21 \%$ and very often $4,2 \%$. Student who admitted to have physical bullying of 24,9\% (male 65,7\%, female 34,3 $\%$ ), verbal $86,4 \%$ (male 85,7\%, female 87\%), and social 25,6\% (male 21,9\%, female $29,1 \%)$. Then the response of students when received unpleasant treatment is silent 56,8 $\%$, trying to prove themselves $55,4 \%$ and ignorant 46,7\%. However, most of the survivors admitted quite successfully to overcome the bullying that be received. The descriptive research give further undersanding for researcher about violence in schools, how survivors response and overcome these acts of violence.
\end{abstract}

Key words: bullying, survivor, students

\section{PENDAHULUAN}

Fenomena bullying di sekolah merupakan bahasan yang sudah sering terdengar dan menjadi topik yang sering muncul di dunia pendidikan. Pendidikan merupakan sebuah usaha yang dilakukan manusia untuk meningkatkan taraf hidup dan berpengaruh terhadap perkembangan fisik, mental dan seluruh aspek kehidupan manusia. Namun dalam kenyataannya, dunia pendidikan sering ternodai oleh berbagai tindakan kekerasan. Penelitian yang dilakukan di sebuah SD di Jakarta menemukan 89,5\% siswa mengaku terlibat dalam bullying, baik sebagai korban maupun pelaku dan $85,6 \%$ siswa yang menjadi korban, mengaku mengalami bullying dua sampai tiga kali dalam sebulan (Soedjatmiko, Nurhamzah, Maureen, \& Wiguna, 2013). Selain itu, penelitian yang dilakukan di Yogyakarta pada 210 siswa sekolah menengah atas dari 5 SMA Negeri dan
Swasta, menemukan $49 \%$ siswa mengalami bullying dan yang paling banyak dialami adalah bullying verbal sebesar 47\% (Marela, Wahab, \& Marchira, 2017). Pendidikan yang bertujuan untuk memaksimalkan fungsi dan tugas perkembangan manusia menjadi berbalik arah karena tindakan bullying di sekolah.

Bullying pada siswa-siswa sekolah adalah fenomena yang sangat tua dan terkenal, namun baru pada awal tahun 1970 an menjadi obyek penelitian yang sistematik (Olweus, 1995). Pemerintah, tokoh-tokoh pendidikan maupun para ahli berusaha mengantisipasi dan mengatasi berbagai permasalahan yang ditimbulkan oleh bullying yang terjadi di sekolah. Namun demikian, fenomena bullying di sekolah masih tetap banyak terjadi bahkan semakin merajalela. Berbagai berita di media massa maupun cerita yang beredar diantara siswa-siswa 
sekolah menunjukkan bahwa bullying tetap tumbuh subur dilingkup dunia pendidikan.

Menurut Salmivalli, Peets \& Hodges (2011) bullying adalah salah satu tipe khusus dari perilaku agresif yang menimbulkan tekanan atau menyakiti bagi orang lain, serta menunjukkan ketidakseimbangan kekuasaan, dan diulang dari waktu ke waktu. Bullying dikarakteristikkan dengan tiga kriteria yaitu merupakan perilaku agresif yang disengaja, dilakukan secara berulangulang dan setiap waktu, serta adanya relasi kekuatan yang tidak seimbang (Salmivalli et al., 2011). Pelaku bullying pada umumnya memiliki kekuatan atau kekuasaan yang lebih besar dari korban bullying. Tindakan bullying yang berupa kekerasan fisik pada siswa SMP di kecamatan Trawas (Januarko \& Setiawati, 2013) dilakukan oleh siswa senior kepada siswa yunior dikarenakan siswa senior merasa memiliki kekuatan atau kekuasaan yang lebih besar dari siswa yunior. Siswa yang terkena aksiaksi negatif biasanya mengalami kesulitan dalam mempertahankan dirinya dan tidak berdaya melawan siswa-siswa yang mengganggunya (Olweus, 1997). Bullying berbeda dengan konflik, pertengkaran, atau pertikaian antara dua individu yang memiliki kedudukan yang sama dalam hal psikologis atau kekuatan fisik maupun status sosial (Salmivalli et al., 2011).

Kekerasan dibagi menjadi beberapa bentuk (Fernández, Fernández, Castro, Failde Garrido, \& Otero, 2013) yaitu pengucilan secara sosial yang meliputi pengabaian, penolakan dan tidak boleh berpartisipasi. Bentuk kekerasan yang kedua adalah kekerasan verbal yang terdiri dari penghinaan, memanggil nama dengan ejekan, dan berbicara buruk. Selanjutnya adalah kekerasan fisik tidak langsung seperti menyembunyikan sesuatu, memecahkan barang, mencuri barang serta kekerasan fisik langsung seperti memukul. Ancaman dalam bentuk menakut-nakuti, memaksa dengan ancaman, mengancam dengan senjata serta kekerasan seksual seperti intimidasi dengan penghinaan seksual, memaksa untuk berpartisipasi dalam situasi seksual merupakan bentukbentuk lain dari kekerasan. Bentukbentuk kekerasan tersebut di atas, sedikit berbeda dari bentuk-bentuk kekerasan yang disampaikan oleh Hymel \& Swearer (2015) yang membagi kekerasan dalam bentuk kekerasan fisik langsung (bullying fisik); ejekan dan ancaman verbal (bullying verbal); pengucilan, penghinaan, dan penyebaran rumor (bullying relasional atau sosial); dan pelecehan secara elektronik menggunakan teks, e-mail, atau media online (cyberbullying). Hymel \& Swearer (2015) menambahkan bahwa bullying fisik dan cyberbullying sering kali menimbulkan kekhawatiran yang paling besar, namun demikian intimidasi sosial dan verbal lebih umum dialami oleh siswa.

Penelitian yang dilakukan di distrik-distrik USA oleh (Black, Weinles, \& Washington, 2010) pada siswa-siswa kelas 5-8, dengan 82,7\% subyek penelitian berasal dari keturunan afrika-amerika, menemukan bahwa $50 \%$ siswa melaporkan terjadi kekerasan minimal dua kali dalam sebulan atau lebih. Demikian pula yang terjadi pada siswa di Australia (Lester \& Mander, 2015). Berdasarkan hasil penelitian pada siswa berasrama kelas 7 dilaporkan bahwa $22 \%$ pernah menjadi korban (satu atau dua kali dalam 10 bulan terakhir) dan $16 \%$ mengaku sering menjadi korban. Hasil penelitian tersebut juga menunjukkan bahwa dengan semakin meningkatnya kelas mereka (8 dan 9) prosentase yang menjadi korban semakin meningkat, terutama untuk anak lakilaki.

Penelitian lain yang dilakukan di Spanyol pada 1500 siswa yang mengikuti wajib belajar pendidikan menengah pada tahun akademik 2007-2008 mengungkapkan bahwa prevalensi subjek yang menjawab "sangat sering" 
adalah $16.3 \%$ sebagai korban, 20.6\% sebagai pelaku dan $52.7 \%$ sebagai penonton atau saksi (Carrera Fernández et al., 2013). Demikian pula hasil penelitian pada siswa kelas 7 di Taiwan menunjukkan bahwa cukup banyak responden yang sudah mengalami kekerasan oleh teman sebaya di semester pertama sekolah menengah (Wei, Jonson-Reid, \& Tsao, 2007). Penelitianpenelitian tersebut di atas menunjukkan bahwa kekerasan di sekolah merupakan kejadian yang terdapat pada seluruh bagian muka bumi, baik di benua Amerika, Eropa maupun Asia.

Penelitian yang dilakukan oleh Yayasan Semai Jiwa Amini (Sejiwa, 2008) tentang fenomena bullying yang terjadi pada tiga kota besar di Indonesia yaitu Jakarta, Surabaya dan Yogyakarta, menemukan bahwa terjadinya tingkat kekerasan pada tingkat SMA adalah sebesar 67,9\% dan tingkat SMP sebesar $66,1 \%$. Bullying di sekolah tidak hanya terjadi pada kota-kota besar. Bullying di sekolah juga merambah pada kota-kota kecil di Indonesia. Hasil penelitian awal yang dilakukan oleh (Januarko \& Setiawati, 2013) pada siswa Sekolah Menengah Pertama di kecamatan Trawas, Mojokerto Jawa Timur menemukan bahwa kekerasan fisik pada SMP Negeri 1 Trawas sebesar 48,1\%, SMP Negeri 2 Trawas sebesar 50,4\% dan SMP Penanggungan sebesar $61 \%$. Sedangkan kekerasan psikologis untuk SMP Negeri 1 Trawas sebesar 31,9\%, SMP Negeri 2 Trawas sebesar 49,3\% dan SMP Penanggungan sebesar 54,3\%.

Fenomena bullying tidak hanya terjadi di sekolah menengah saja. Penelitian yang dilakukan oleh (Kevorkian et al., 2016) di Massachusetts USA menemukan bahwa $40 \%$ siswa kelas 3-5 SD dilaporkan menjadi korban bullying. Demikian pula penelitian yang dilakukan di Indonesia. Berdasarkan studi awal yang dilakukan oleh (Dinardinata \& Kumara, 2015) bahwa 48,78\% dari 123 guru-guru TK melaporkan bahwa adanya siswa yang seringkali menjadi korban bullying dari teman-teman sesama siswa TK. Fenomena ini menunjukkan bahwa fenomena bullying sudah muncul sejak anak-anak memasuki usia prasekolah. Gejala tersebut di atas menjadi sebuah bentuk kenyataan bahwa bullying telah menjadi fenomena umum dalam dunia pendidikan.

Bullying tidak hanya merugikan bagi korban namun juga bagi pelaku bullying. Berbagai penelitian menemukan bahwa siswa yang terlibat dalam bullying, khususnya sebagai pelaku maupun korban, seringkali ditemukan mengalami problem-problem perilaku. Anak-anak yang telah menjadi korban bullying berada pada tingkat yang signifikan memiliki risiko lebih tinggi untuk mengalami gangguan kejiwaan. Anak-anak yang menjadi korban bullying memiliki kecemasan sosial yang lebih besar dan keinginan bunuh diri (Silberg et al., 2016). Hal ini di dukung oleh Pranjic \& Bajraktarevic (2010) yang menyatakan bahwa ada peningkatan prevalensi depresi dan keinginan bunuh diri pada remaja yang menjadi korban bullying daripada remaja yang tidak terlibat dalam bullying. Selain itu penelitian lain juga menemukan bahwa siswa yang menjadi korban bullying memiliki prestasi sekolah dan kelekatan dengan sekolah yang rendah (Dake, Price, \& Telljohann, 2003; Schneider, Donnell, Stueve, \& Coulter, 2012). Berbagai efek negatif dialami oleh korban bullying baik dalam jangka pendek maupun jangka panjang. Banyak ahli menyatakan bullying mam-pu memberikan efek negatif jangka panjang bagi para korban hingga mereka dewasa (Arseneault, Bowes, \& Shakoor, 2010).

Penelitian ini dilakukan pada siswa-siswi SMA dan SMK Negeri dan Swasta di kota Semarang. Semarang merupakan ibu kota Jawa Tengah yang terletak di bagian tengah pulau Jawa. Sebagian besar penduduk kota Semarang adalah masyarakat dari suku Jawa, meskipun tidak dipungkiri ada pula yang 
bukan berasal dari suku Jawa. Oleh karena itu dalam penelitian ini, siswa yang bukan bersuku Jawa tidak dimasukkan sebagai partisipan penelitian. Menurut (Koentjaraningrat, 1984) orang Jawa berasal dari pulau Jawa, khususnya di propinsi Jawa Tengah dan Jawa Timur, akan tetapi di daerah itu tinggal juga orang-orang yang bukan orang Jawa. Ditambahkan oleh (Magnis-suseno, 1985) bahwa orang Jawa adalah penduduk asli bagian tengah dan timur pulau Jawa yang berbahasa Jawa.

Pola pergaulan dalam masyarakat jawa terdiri dari dua kaidah (Magnissuseno, 1985). Kaidah pertama mengatakan bahwa dalam setiap situasi manusia hendaknya bersikap sedemikian rupa sehingga tidak sampai menimbulkan konflik. Kaidah ini disebut dengan prinsip kerukunan. Kaidah kedua menuntut manusia supaya selalu menunjukkan sikap hormat pada orang lain, sesuai dengan derajat dan kedudukannya. Kaidah ini disebut sebagai prinsip hormat. Kedua kaidah tersebut menjadi kerangka normatif yang menentukan bentuk-bentuk konkret dalam semua interaksi orang Jawa.

Berdasarkan prinsip-prinsip tersebut, peneliti melihat bahwa pola interaksi pada masyarakat Jawa lebih menekankan pada prinsip kerukunan dan hormat. Oleh karena itu diharapkan bullying antar siswa di kota Semarang memiliki kadar yang lebih minimal. Namun demikian melihat fenomena diberbagai tempat tentang kasus bullying yang semakin meningkat, peneliti tertarik untuk mengetahui bagaimana prevalensi siswa (baik siswa laki-laki maupun perempuan) yang pernah menjadi korban bullying di kota Semarang. Dengan mengetahui preva-lensi siswa yang pernah menjadi korban bullying, maka akan dapat membantu memberikan gambaran secara lebih menyeluruh tentang jenis-jenis bullying yang dialami oleh siswa korban bullying di kota Semarang, bagaimana cara mereka merespon tindakan kekerasan yang dilakukan oleh teman-temannya tersebut, serta bagaimana persepsi mereka terhadap tingkat keberhasil-annya dalam mengatasi tindakan bullying yang pernah mereka alami.

Tujuan dari penelitian ini adalah untuk mengetahui:

1. Prevalensi siswa yang pernah menjadi korban bullying di sekolah (siswa laki-laki dan perempuan) di kota Semarang

2. Bentuk-bentuk bullying yang dialami

3. Respon korban dalam menghadapi bullying yang mereka alami

4. Persepsi korban bullying terhadap keberhasilan mereka mengatasi tindakan bullying

\section{METODE}

Penelitian ini merupakan penelitian deskriptif. Partisipan penelitian adalah siswa kelas 10 dan 11 dengan jumlah 731 siswa dari enam SMA/SMK di kota Semarang. Teknik pengambilan sampel menggunakan teknik purposive sampling. Teknik purposive sampling adalah teknik pengambilan sampel yang tidak didasarkan pada random, melainkan atas adanya pertimbangan-pertimbangan yang berfokus pada tujuan tertentu (Hadi, 1993).

Instrumen yang digunakan dalam penelitian ini adalah kuesioner yang disusun sendiri oleh peneliti berdasar pada penelitian yang dilakukan oleh Sagger et al (2017), Black et al (2010) dan Fernandez et al ( 2013). Bentuk bullying terdiri dari bullying fisik, verbal dan sosial. Sedangkan jenis perlakuan berdasar bentuk bullying yaitu bullying fisik (dipukul, ditampar, ditendang, di dorong, barang miliknya di rusak), bullying verbal (diejek, dimaki, dipanggil dengan nama ejekan, difitnah), bullying sosial (ditolak, dikucilkan). Selanjutnya respon dan atau strategi yang dilakukan korban bullying adalah respon atau strategi yang bersifat pasif dan aktif. Instrumen disusun dalam bentuk 
kuesioner tertutup dan terbuka. Kuesioner disusun dalam bentuk daftar pertanyaan yang alternatif jawabannya telah disediakan dan responden diberi kesempatan untuk menjawab lebih dari satu. Selain itu responden juga diberi kesempatan untuk mengisi jawaban tambahan sesuai dengan keadaan diri. Pada penelitian ini, pertanyaan kepada responden menggunakan kalimat yang diperhalus dengan tujuan agar subyek penelitian tidak menutup diri. Oleh karena itu penggunaan kata bullying dihindari dan diganti dengan pengalaman yang tidak menyenangkan. Selanjutnya untuk menjamin validitas alat ukur, penelitian ini menggunakan professional judgement.

\section{HASIL}

Keseluruhan partisipan dalam penelitian adalah 731 siswa dan relatif terdistribusi merata secara gender, dengan siswa laki-laki sebesar $47,2 \%$ dan perempuan $52,8 \%$. Hasil penelitian menemukan ada 433 siswa (59,2 \%) pernah menjadi korban bullying ketika SD maupun SMP. Selanjutnya dari siswa berjumlah 433 tersebut, peneliti menggali informasi tentang frekuensi responden menjadi korban bullying. Subyek yang mengaku pernah satu kali menjadi korban sebanyak $11,5 \%$, jarang $63,3 \%$, sering $21 \%$ dan sangat sering 4,2 $\%$. Hasil penelitian juga menemukan siswa laki-laki yang mengaku pernah menjadi korban bullying, berada pada tingkat yang kurang lebih sama dengan siswa perempuan dengan perbandingan $48,5 \%$ dan $51,5 \%$. Hasil ini juga didukung dengan hasil uji beda dengan menggunakan teknik IndependentSample $T$ Test. Hasil analisa data menemukan bahwa nilai $\mathrm{t}=1,653$ dengan $\mathrm{p}=0,099$. Hasil tersebut menunjukkan bahwa $p>0,05$ berarti tidak ada perbedaan frekuensi menjadi korban bullying ditinjau dari jenis kelamin. Hasil ini menunjukkan bahwa siswa laki-laki dan perempuan memiliki frekuensi menjadi korban bullying yang relatif sama.

Bentuk-bentuk bullying yang dialami oleh 433 siswa yang menjadi korban yaitu 24,9 \% mengaku pernah mendapat bullying fisik, 86,4\% bullying verbal dan 25,6 \% bullying sosial. Berikut pada tabel 1 adalah bentukbentuk bullying yang dialami oleh siswa berdasar jenis kelamn

Tabel 1. Bentuk Bullying

\begin{tabular}{ccccc}
\hline Bentuk & N $(\mathrm{Jml}$ & Persentase & \multicolumn{2}{c}{ Persentase } \\
Bullying & respon $)$ & & Laki-laki & Perempuan \\
\hline Fisik & 108 & 24,9 & 65,7 & 34,3 \\
Verbal & 374 & 86,4 & 48,1 & 51,9 \\
Sosial & 111 & 25,6 & 41,4 & 58,6 \\
\hline
\end{tabular}

Berdasarkan data pada tabel 1, siswa lakilaki lebih banyak mengalami bullying fisik dibanding siswa perempuan, dengan perbandingan 71 siswa laki-laki $(65,7 \%)$ dan 37 siswa perempuan (34,3\%). Hasil tersebut juga didukung dengan hasil uji beda dengan menggunakan teknik Independent-Sample T Test. Hasil analisa data menemukan bahwa nilai $\mathrm{t}=4,183$ dengan $p=0,000$. Hasil tersebut menunjukkan bahwa $\mathrm{p}<0,01$ berarti ada perbedaan korban bullying fisik ditinjau dari jenis kelamin, bahwa siswa laki-laki (mean $=0,3381$ ) lebih sering mengalami bullying fisik daripada siswa perempuan (mean $=0,1659)$. Siswa laki-laki mengakui lebih sering mendapatkan bullying fisik dari teman seperti dipukul dan didorong.

Bullying verbal yang dialami siswa laki-laki dan perempuan berada pada tingkat yang kurang lebih sama (laki-laki 
$85,7 \%$ perempuan $87 \%$ ). Hasil ini juga didukung hasil uji beda dengan menggunakan teknik IndependentSample $T$ Test. Hasil analisa data menemukan bahwa nilai $\mathrm{t}=-0,388$ dengan $\mathrm{p}=0,699$. Hasil tersebut menunjukkan bahwa $\mathrm{p}>0,05$ berarti tidak ada perbedaan korban bullying verbal ditinjau dari jenis kelamin. Hasil ini menunjukkan bahwa siswa laki-laki dan perempuan yang menjadi korban bullying verbal relatif sama.

Selanjutnya, berdasarkan hasil uji perbedaan bullying sosial yang dialami oleh siswa laki-laki dan perempuan dengan menggunakan teknik Independent-Sample $T$ Test ditemukan bahwa nilai $\mathrm{t}=-1,727$ dengan $\mathrm{p}=0,085$. Hasil tersebut menunjukkan bahwa $p$ > 0,05 berarti tidak ada perbedaan korban bullying sosial ditinjau dari jenis kelamin. Hasil ini menunjukkan bahwa siswa laki-laki dan perempuan yang menjadi korban bullying sosial relatif sama. Namun demikian berdasarkan nilai rerata ditemukan bahwa siswa perempuan $($ mean $=0,2915)$ lebih sering mengalami bullying sosial dibanding siswa laki-laki (mean=0,2190).

Selanjutnya jenis-jenis perlakuan bullying yang di alami serta persentase perlakuan berdasar jenis kelamin terdapat pada tabel 2 .

Hasil temuan pada tabel 2 juga dapat dilihat bahwa jenis-jenis bullying yang paling banyak dialami adalah jenisjenis bullying verbal dimulai dari diejek sebesar $41,3 \%$, dipanggil dengan nama ejekan $21,2 \%$, difitnah $16,9 \%$ dan dimaki $12,5 \%$. Selanjutnya jenis bullying fisik yang paling banyak terjadi adalah didorong sebesar $9,2 \%$, sedangkan bullying sosial yang paling banyak terjadi adalah dikucilkan sebesar 13,4\%.

Tabel 2. Jenis Perlakuan Bullying

\begin{tabular}{|c|c|c|c|c|c|}
\hline & \multirow{2}{*}{ Jenis Perlakuan } & \multirow{2}{*}{$\begin{array}{l}\mathrm{N}(\mathrm{Jm} l \\
\text { respon) }\end{array}$} & \multirow{2}{*}{$\begin{array}{c}\text { Persent } \\
\text { ase }\end{array}$} & \multicolumn{2}{|c|}{ Persentase } \\
\hline & & & & Laki-laki & Perempuan \\
\hline \multirow[t]{6}{*}{ Fisik } & Dipukul & 37 & 8,5 & 70,3 & 29,7 \\
\hline & Ditampar & 11 & 2,5 & 63,6 & 36,4 \\
\hline & Ditendang & 20 & 4,6 & 70,0 & 30,0 \\
\hline & Dido rong & 40 & 9,2 & 67,5 & 32,5 \\
\hline & Barang miliknya dirusak & 39 & 9 & 46,2 & 53,8 \\
\hline & Lain2 & 9 & 2,1 & 44,4 & 55,6 \\
\hline \multirow[t]{5}{*}{ Verbal } & Diejek & 179 & 41,3 & 48,1 & 51,9 \\
\hline & $\begin{array}{l}\text { Dipanggil dengan nama } \\
\text { ejekan }\end{array}$ & 92 & 21,2 & 47,5 & 52,5 \\
\hline & Dimaki & 54 & 12,5 & 55,4 & 44,6 \\
\hline & Difitnah & 73 & 16,9 & 46,6 & 53,4 \\
\hline & Lain2 & 15 & 3,5 & 26,7 & 73,3 \\
\hline \multirow[t]{3}{*}{ Sosial } & Ditolak & 22 & 5,1 & 63,6 & 36,4 \\
\hline & Dikucilkan & 58 & 13,4 & 41,4 & 58,6 \\
\hline & Lain2 & 23 & 5,3 & 43,5 & 56,5 \\
\hline
\end{tabular}

Tahap selanjutnya dalam penelitian ini adalah mengetahui bagaimana respon dan atau strategi yang dilakukan korban ketika mendapat perlakuan tidak menyenangkan dari teman. Tabel 3 melaporkan tentang respon partisipan ketika mereka menjadi korban bullying. Hasil penelitian menemukan $56,8 \%$ siswa memilih diam saja ketika mereka menjadi korban, diikuti dengan berjuang membuktikan diri $55,4 \%$, cuek $46,7 \%$ dan melawan $40,9 \%$. Siswa yang berespon dengan cara melapor kepada orang dewasa ternyata hanya sebesar $20,6 \%$. 
Tabel 3. Respon menghadapi bullying

\begin{tabular}{lcc}
\hline \multicolumn{1}{c}{ Jenis Respon } & Jumlah respon & Persentase \\
\hline Sedih & 101 & $23,3 \%$ \\
Menangis & 63 & $14,5 \%$ \\
Diam saja & 246 & $56,8 \%$ \\
Prestasi sekolah turun & 31 & $7,2 \%$ \\
Tidak mau sekolah & 19 & $4,4 \%$ \\
Menyendiri & 68 & $15,7 \%$ \\
Tertekan & 96 & $22,2 \%$ \\
Melawan & 177 & $40,9 \%$ \\
Cuek & 202 & $46,7 \%$ \\
Putus asa & 5 & $1,2 \%$ \\
Lapor pada orang dewasa & 89 & $20,6 \%$ \\
Membuktikan diri & 240 & $55,4 \%$ \\
Lain-lain & 55 & $12,7 \%$ \\
\hline
\end{tabular}

$\begin{aligned} \text { Peneliti selanjutnya } & \text { membuktikan diri }(58,7 \%) \text {, cuek } \\ \text { mengelompokkan secara khusus } & (48,6 \%) \text {, tertekan }(39,4 \%) \text {, melawan } \\ \text { responden yang mengaku sering dan } & (38,5 \%) \text { dan melapor pada orang dewasa } \\ \text { sangat sering menjadi korban bullying. } & (30,3 \%) \text {. Secara rinci dapat dilihat pada } \\ \text { Hasil analisa menemukan respon mereka } & \text { tabel } 4 .\end{aligned}$
berturut-turut dari yang terbesar adalah diam saja $(61,5 \%)$, berjuang

Tabel 4. Respon menghadapi bullying (pada partisipan yang sering dan sangat sering menjadi korban)

\begin{tabular}{lcc}
\hline \multicolumn{1}{c}{ Jenis Respon } & Jumlah respon & Persentase \\
\hline Sedih & 32 & $29,4 \%$ \\
Menangis & 28 & $25,7 \%$ \\
Diam saja & 67 & $61,5 \%$ \\
Prestasi sekolah turun & 15 & $13,8 \%$ \\
Tidak mau sekolah & 12 & $11 \%$ \\
Menyendiri & 30 & $27,5 \%$ \\
Tertekan & 43 & $39,4 \%$ \\
Melawan & 42 & $38,5 \%$ \\
Cuek & 53 & $48,6 \%$ \\
Putus asa & 4 & $3,7 \%$ \\
Lapor pada orang dewasa & 33 & $30,3 \%$ \\
Membuktikan diri & 64 & $58,7 \%$ \\
Lain-lain & 15 & 13,8 \\
\hline
\end{tabular}

Selanjutnya penilaian diri responden terhadap kemampuannya mengatasi bullying yang pernah mereka alami adalah 14 siswa $(3,2 \%)$ menilai diri tidak berhasil mengatasi, 48 siswa $(11,1 \%)$ kurang berhasil, 270 siswa $(62,4$ $\%)$ cukup berhasil dan 99 siswa $(22,9 \%)$ menilai diri sangat berhasil dalam mengatasi bullying yang pernah mereka alami.

\section{DISKUSI}

Berdasarkan hasil penelitian ditemukan ada 433 siswa $(59,2 \%)$ dari 731 responden yang mengaku pernah menjadi korban bullying di sekolah. Hasil penelitian ini menunjukkan bahwa 
meskipun prinsip rukun dan hormat menjadi kerangka normatif dalam berelasi pada masyarakat Jawa, namun bullying tetap tumbuh dengan subur. Bullying adalah fenomena yang sangat tua dan sering muncul di sekolah (Olweus, 1995). Selanjutnya dari siswa berjumlah 433 tersebut, peneliti menggali informasi tentang frekuensi responden menjadi korban bullying. Subyek yang mengaku pernah satu kali menjadi korban sebanyak $11,5 \%$, jarang $63,3 \%$, sering $21 \%$ dan sangat sering 4,2 $\%$. Hasil ini sedikit berbeda dengan hasil penelitian yang dilakukan pada siswa di Australia (Lester \& Mander, 2015). Berdasarkan hasil penelitian pada siswa berasrama kelas 7 tersebut dilaporkan bahwa $22 \%$ pernah menjadi korban (satu atau dua kali dalam 10 bulan terakhir) dan $16 \%$ mengaku sering menjadi korban. Hasil penelitian ini juga menemukan bahwa responden yang mengakui menjadi korban bullying dalam kategori sering dan sangat sering adalah $25,2 \%$ dari 433 siswa. Temuan ini tidak jauh berbeda dengan penelitian yang dilakukan (Carrera Fernández et al., 2013) pada siswa sekolah menengah di Spanyol bahwa prevalensi subyek yang menjawab "sangat sering" sebagai korban adalah $16.3 \%$.

Bullying verbal mendominasi perilaku bullying yang terjadi di sekolah yaitu $86,4 \%$. Penyalahgunaan verbal terbukti menjadi jenis perilaku kasar yang paling umum (Carrera Fernández et al., 2013) dan ini di dukung pula oleh penelitian yang dilakukan (Marela et al., 2017) yang menemukan bahwa bullying yang paling banyak dialami remaja adalah bullying verbal sebesar $47 \%$. Fenomena ini diduga karena kemungkinan bullying verbal masih dianggap wajar bagi sebagian besar masyarakat dan tidak ada konsekuensi negatif bagi pelaku, sehingga bullying verbal tetap tumbuh dengan subur.

Perilaku bullying dapat dijelaskan dengan menggunakan teori dominansi sosial. Teori dominansi sosial berpendapat bahwa penindasan antar kelompok, diskriminasi, dan prasangka adalah cara manusia mengatur diri mereka sendiri sebagai hierarki berbasis kelompok, di mana anggota kelompok dominan mempertahankan bagian halhal baik dalam hidup dan anggota kelompok yang tidak dominan menerima proporsi hal-hal yang buruk dalam hidup (Sidanius \& Pratto, 2012). Bullying adalah tindakan agresi yang dilakukan oleh seseorang atau kelompok terhadap seseorang atau kelompok lain dengan karakteristik utama terjadi ketidakseimbangan kekuatan antara pelaku dan korban. Pelaku bullying adalah mereka yang berada di kelompok dominan dan korban berada pada kelompok tidak dominan. Anggota kelompok dominan akan berusaha mempertahankan hal-hal baik dalam hidupnya sehingga tindakan agresi mereka lakukan untuk mempertahankan hal-hal baik tersebut.

Pada teori ini, hierarki sosial berbasis kelompok terdiri dari tiga sistem stratifikasi yang berbeda yaitu sistem umur, sistem jenis kelamin dan sistem kesewenang-wenangan. Sistem umur yaitu orang dewasa memiliki kekuatan yang tidak seimbang terhadap orang dewasa yang lebih muda dan anak-anak. Sistem jenis kelamin yaitu laki-laki memiliki kekuatan sosial dan politik yang tidak seimbang dibanding perempuan dan sistem kesewenangwenangan, yang dibangun atas dasar kesewenang-wenangan dan tidak berhubungan dengan siklus kehidupan manusia. Sistem ini dibangun berdasarkan kekuatan dan legitimasi dengan kategori sosial seperti suku, agama, kepemilikan, pengetahuan, ketrampilan dan lain-lain (Sidanius \& Pratto, 2012)

Jenis kelamin merupakan salah satu sistem yang digunakan dalam teori dominansi sosial untuk menentukan hirarki sosial manusia. Demikian pula dalam penelitian ini, jenis kelamin digunakan untuk membedakan berbagai 
tindakan bullying yang terjadi di sekolah. Penelitian pada siswa sekolah menengah di Izmir Turki menunjukkan bahwa perempuan cenderung tidak terlibat atau menjadi korban bullying, sedangkan lakilaki cenderung menjadi pelaku dan pelaku/ korban (Özer, Totan, \& Atik, 2011). Namun dalam penelitian ini dilaporkan bahwa tidak ada perbedaan frekuensi menjadi korban bullying ditinjau dari jenis kelamin. Siswa lakilaki maupun perempuan memiliki frekuensi menjadi korban bullying yang relatif sama.

Penelitian ini juga menggali informasi tentang bagaimana korban bullying merespon tindakan bullying yang mereka terima. Jawaban 'diam saja' memiliki persentase terbesar yang dipilih oleh responden yang pernah menjadi korban bullying di sekolah yaitu sebesar $56,8 \%$. Hasil ini berbeda dengan temuan penelitian yang dilakukan oleh (Black et al., 2010) terhadap siswa-siswa yang menjadi korban bullying di Amerika Serikat. Mereka memilih melawan (63\%) sebagai strategi dalam menghadapi bullying yang mereka alami. "Diam" kemungkinan merupakan bagian dari karakter orang Jawa yang menekankan pentingnya menjaga hubungan baik dengan orang lain. Respon "diam" adalah upaya korban supaya hubungan atau relasinya dengan pelaku bullying tetap terjaga dengan baik. (Koentjaraningrat, 1984) mengatakankan bahwa orang Jawa biasanya menilai tinggi perilaku yang berusaha untuk menjaga hubungan baik dengan orang lain.

Pola relasi pada masyarakat Jawa menekankan pada prinsip kerukunan. Prinsip kerukunan bertujuan untuk mempertahankan masyarakat dalam keadaan yang harmonis. Berperilaku rukun berarti menghilangkan tanda-tanda ketegangan dalam masyarakat atau antara pribadi-pribadi sehingga hubungan sosial tetap kelihatan selaras (Magnis-suseno, 1985). Perilaku'diam' yang dilakukan para korban bullying pada penelitian ini dimaksudkan sebagai usaha korban bullying untuk menghilangkan atau menyingkirkan unsur-unsur yang mungkin menimbulkan perselisihan.

Namun demikian, diam sebenarnya dapat dimaknai secara berbeda-beda. Orang tua Jawa cenderung menanamkan suatu pandangan yang bersifat pesimis mengenai hidup di dunia dan mereka sengaja mengajarkan perasaan takut (wedi) kepada anakanaknya (Koentjaraningrat, 1984). Hal ini kemungkinan menimbulkan perasaan takut anak-anak pada orang lain. Perasaan takut (wedi) mungkin saja menjadi alasan korban bullying untuk tidak melawan ketika mereka mendapat perlakuan tidak menyenangkan. Selain itu budaya Jawa juga mengenalkan tentang pentingnya nilai budaya secara vertikal. Budaya ini menekankan pentingnya menghormati orang-orang yang lebih senior. Bullying biasanya terjadi karena adanya ketidakseimbangan kekuatan antara korban dan pelaku. Kekuatan dapat diasosiasikan dengan senioritas dan bullying banyak dilakukan oleh kakak kelas terhadap adik kelas. Oleh karena itu, kemungkinan makna "diam" bisa saja karena adanya rasa hormat adik kelas terhadap kakak kelas. Prinsip hormat memainkan peranan penting dalam mengatur pola interaksi masyarakat Jawa. Prinsip ini mengatakan bahwa orang Jawa dalam cara berbicara dan membawa diri selalu harus menunjukkan sikap hormat terhadap orang lain sesuai dengan derajat dan kedudukannya. Oleh karena itu mereka yang berkedudukan tinggi harus diberi hormat (Magnis-suseno, 1985).

Hasil terakhir dari penelitian ini adalah berusaha mengungkap bagaimana persepsi korban bullying menilai keberhasilannya menghadapi tindakan bullying yang mereka terima dari teman. Hasil penelitian menemukan bahwa 85,3 $\%$ responden menyatakan bahwa mereka cukup dan sangat berhasil mengatasi masalah ini. Hasil penelitian ini merupakan salah satu jalan bagi peneliti untuk melakukan penelitian selanjutnya 
tentang resiliensi korban bullying. Resiliensi adalah ide yang mengacu pada kapasitas sistem dinamis untuk bertahan atau pulih dari gangguan (Masten, 2007). Resiliensi merupakan salah satu alternatif bagi korban bullying untuk dapat bertahan atau bangkit dari keterpurukan akibat dari bullying yang mereka terima.

\section{SIMPULAN}

Bullying merupakan fenomena yang sudah sangat tua dan sering terjadi di dunia pendidikan. Bullying di sekolah menimbulkan keprihatinan bagi banyak orang, karena sekolah merupakan tempat bagi anak-anak menimba ilmu dan mengembangkan diri. Hasil penelitian menemukan ada 433 siswa $(59,2 \%)$ pernah menjadi korban bullying ketika SD maupun SMP dan 25,2\% mengakui sering serta sangat sering menjadi korban bullying. Bentuk-bentuk bullying yang dialami adalah $24,9 \%$ bullying fisik, 86,4 $\%$ bullying verbal dan 25,6 \% bullying sosial. Hasil penelitian juga menemukan bahwa sebagian besar korban memilih diam $(56,8 \%)$ ketika mendapat perlakuan tidak menyenangkan. Penelitian ini merupakan penelitian deskriptif yang belum mengungkap hasil secara detil dan mendalam. Oleh karena itu disarankan bagi peneliti selanjutnya untuk dapat menggali informasi secara lebih detil dan mendalam sehingga usaha prevensi dan intervensi terhadap bullying di sekolah dapat lebih efektif.

\section{DAFTAR PUSTAKA}

Arseneault, L., Bowes, L., \& Shakoor, S. (2010). Bullying victimization in youths and mental health problems: ' Much ado about nothing '? Psychological Medicine, 40, 717-729. https://doi.org/10.1017/S0033291 709991383
Black, S., Weinles, D., \& Washington, E. (2010). Victim Strategies to Stop Bullying. Youth Violence and Juvenile Justice, 8(2), 138-147. https://doi.org/10.1177/15412040 09349401

Fernández, C.M. V., Fernández, M. L., Castro, Y. R., Failde Garrido, J. M., \& Otero, M. C. (2013). Bullying in spanish secondary schools: Gender-based differences. Spanish Journal of Psychology, 16(e21), 1-14. https://doi.org/10.1017/sjp.2013.3 7

Dake, J. A., Price, J. H., \& Telljohann, S. K. (2003). The nature and extent of bullying at school. The Journal of School Health, 73(5), 173-180.

Dinardinata, A., \& Kumara, A. (2015). Pengaruh the anti bullying and teasing program tema komunitas dalam menurunkan frekuensi perilaku bullying di kelas taman kanak-kanak. Jurnal Psikologi Undip, 14(1), 58-68.

Hadi, S. (1993). Statistik 2. Yogyakarta: Andi Offset.

Hymel, S., \& Swearer, S. M. (2015). Four decades of research on school bullying. American Psychologist, 70(4), 293-299. https://doi.org/http://dx.doi.org/10 $.1037 / \mathrm{a} 0038928$

Januarko, W., \& Setiawati, D. (2013). Studi tentang penanganan korban bullyimg pada siswa SMP sekecamatan trawas. Jurnal BK UNESA, 04(02), 383-389.

Kevorkian, M. M., Rodriguez, A., Earnhardt, M. P., Kennedy, T. D., D'Antona, R., Russom, A. G., \& Borror, J. (2016). Bullying in elementary schools. Journ Child Adol Trauma, 9, 267-276. https://doi.org/10.1007/s40653016-0085-0 
Koentjaraningrat. (1984). Kebudayaan Jawa. Jakarta: Balai Pustaka.

Lester, L., \& Mander, D. (2015). The role of social, emotional and mental wellbeing on bullying victimisation and perpetration of secondary school boarders. Journal of Psychologists and Counsellors in Schools, 25(2), 152-169.

https://doi.org/10.1017/jgc.2014.2 8

Magnis-suseno, F. (1985). Etika Jawa. Jakarta: PT Gramedia.

Marela, G., Wahab, A., \& Marchira, C. R. (2017). Bullying verbal menyebabkan depresi remaja SMA kota yogyakarta. Berita Kedokteran Masyarakat, 33(1), 83-89.

https://doi.org/10.22146/bkm.818 3

Masten, A. (2007). Resilience in developing systems: Progress and promise as the fourth wave rises. Development and Psychopathology, 19, 921-930. https://doi.org/10.1017/S0954579 407000442

Olweus, D. (1995). Bullying or peer abuse at school: Facts and intervention. Current Directions in Psychological Science, 4(6), 196200. https://doi.org/10.1111/14678721.ep10772640

Olweus, D. (1997). Bully / victim problems in school: Facts and intervention. European Journal of Psychology of Education, XlI(4), 495-510.

https://doi.org/10.1007/BF031728 07
Özer, A., Totan, T., \& Atik, G. (2011). Individual correlates of bullying behaviour in turkish middle schools. Australian Journal of Guidance and Counselling, 21(2), 186-202.

https://doi.org/10.1375/ajgc.21.2. 186

Pranjic, N., \& Bajraktarevic, A. (2010). Depression and suicide ideation among secondary school adolescents involved in school bullying. Primary Health Care Research \& Development, 11, 349-362.

https://doi.org/10.1017/S1463423 610000307

Saggers, B., Campbell, M., Dillonwallace, J., Ashburner, J., Hwang, Y.-S., Carrington, S., \& Tones, M. (2017). Understandings and Experiences of Bullying: Impact on Students on the Autism Spectrum *. Australasian Journal OfSpecial Education, 41(2), 123140.

https://doi.org/10.1017/jse.2017.6

Salmivalli, C., Peets, K., \& Hodges, E. V. E. (2011). Bullying. In Smith and Hart (Ed.), Handbook of childhood social development (Second edi). Blackwell Publishing Ltd.

Schneider, S. K., Donnell, L. O., Stueve, A., \& Coulter, R. W. S. (2012). Cyberbullying, school bullying, and psychological distress: A regional census of high school students. American Journal of Public Health, 102(1), 171-178. https://doi.org/10.2105/AJPH.201 1.300308

Sejiwa. (2008). Bullying: Mengatasi Kekerasan di Sekolah dan Lingkungan Sekitar Anak. Jakarta: Grasindo. 
Sidanius, J., \& Pratto, F. (2012). Social dominance theory. In P. A. . Van Lange, A. . Kruglanski, \& E. . Higgins (Eds.), Handbook of Theories of Social Psychology. London: Sage Publications Ltd.

Silberg, J. L., Copeland, W., Linker, J., Moore, A. A., Roberson-Nay, R., \& York, T. P. (2016). Psychiatric outcomes of bullying victimization: A study of discordant monozygotic twins. Psychological Medicine, 46, 1875-1883.

https://doi.org/10.1017/S0033291

716000362
Soedjatmiko, S., Nurhamzah, W., Maureen, A., \& Wiguna, T. (2013). Gambaran bullying dan hubungannya dengan masalah emosi dan perilaku pada anak sekolah dasar. Sari Pediatri, 15(3), 174-180.

https://doi.org/10.14238/sp15.3.20 13.174-80

Wei, H. S., Jonson-Reid, M., \& Tsao, H. L. (2007). Bullying and victimization among Taiwanese 7th graders: A multi-method assessment. School Psychology International, 28(4), 479-500. https://doi.org/10.1177/01430343 07084137 